32. Rojanasathit, S., and Haddad, J.: Characterization of a new human calcitonin (HCT) radioimmunoassay (RIA). Clin. Chim. Acta (In press.)

33. Root, A., and Harrison, H.: Recent advances in calcium metabolism. I. Mechanisms of calcium homeostasis. J. Pediat., 88: 1 (1976).

34. Rosen, J., Roginsky, M., Nathenson, G., and Finberg, L.: 25-Hydroxyvitamin D: Plasma levels in mothers and their premature infants with neonatal hypocalcemia. Amer. J. Dis. Child., 127: 220 (1974).

35. Sorenson, $O$., Nellesen, $C$., and Hindberg, I.: The effect of diet and age on the response to calcitonin in rats. Acta Endocrinol., 65: 316 (1970).

36. Stamp, T., and Round, J.: Seasonal changes in human plasma levels of 25hydroxy-vitamin D. Nature, 274: 563 (1974).

37. Suh, S., Tashjian, A., Jr., Matsuro, N., Parkinson, E., and Fraser, D.: Pathogenesis of hypocalcemia in primary hypomagnesemia: Normal endorgan responsiveness to parathyroid hormone, impaired parathyroid gland function. J. Clin. Invest., 52: 153 (1973).

38. Tsang, R.: Neonatal magnesium disturbances. Amer. J. Dis. Child., 124: 282 (1972).

39. Tsang, R., Chen, I.-W., Friedman, M., and Chen, I.: Neonatal parathyroid function: Role of gestational age and postnatal age. J. Pediat., 83: 728 (1973).

40. Tsang, R., Chen, I.-W., Friedman, M., Gigger, M., Steicher, J., Koffler, H., Fenton, L., Brown, D., Pramanik, A., Keenan, W., Stub, R., and Joyce, T.: Parathyroid function of infants of diabetic mothers. J. Pediat., 86: 399 (1975).

41. Tsang, R., Light, I., Sutherland, J., and Kleinman, L. I.: Possible pathogenetic factors in neonatal hypocalcemia of prematurity. J. Pediat., 82: 423
(1973).

42. Tsang, $R$, and $\mathrm{Oh}, \mathrm{W}$. Serum magnesium levels in low birth weight infants Amer. J. Dis. Child., 120: 44 (1970).

43. Tsang, R., and Oh, W.: Neonatal hypocalcemia in low birth weight infants Pediatrics, 45: 773 (1970).

44. Tsang, R., Strub, R., Brown, D., Streicher, J., Hartman, C., and Chen, I.W.: Hypomagnesia in infants of diabetic mothers: Perinatal studies. J. Pediat., 89: 115 (1976).

45. Watney, P., Chance, G., Scott, P., and Thomposn, J.: Maternal factors in neonatal hypocalcemia: A study in three ethnic groups. Brit. Med. J., 2: 432 (1971).

46. Wright, D., Ivey, J., and Tashjian, A.: Self-induced loss of calcitonin receptors in bone: a possible explanation for "escape." Clin. Res., 24: 461 A (1976).

47. We thank Dr. John Babcock of the Upjohn Company for his gift of reference 25-hydroxycholecalciferol, Mrs. S. Rei for her technical assistance, and Dr. Gerald Kessler for performing serum chemical analyses.

48. Dr. John G. Haddad is recipient of National Institutes of Health Career Development Award IK 8AM70, 343.

49. This research was supported by National Institute of Arthritis and Metabolic Disease Research Grants AM-05248 and AM-09976 and National Institutes of Health Grant AM 14570-06.

50. Requests for reprints should be addressed to: L. S. Hillman, M.D., St. Louis Children's Hospital, 500 S. Kingshighway, St. Louis, Mo., 63110 (USA).

51. Received for publication August 20, 1976.

52. Accepted for publication October 21,1976
Apgar score lipid

blood

cholesterol

gel filtration lipoporteins

ultracentrifugation umbilical cords

\title{
Separation and Characterization of Cord Serum Lipoproteins
}

\author{
M. D. MORRIS, ${ }^{(21)}$ J. A. LEE, AND M. R. BALDWIN \\ Departments of Pediatrics, Biochemistry, and Obstetrics-Gynecology and University of Arkansas for Medical \\ Sciences, Little Rock, Arkansas, USA
}

\section{Summary}

Blood was collected from the umbilical cords of infants with a 1-min Apgar score of 9 or 10. Total cord serum lipoproteins were isolated by ultracentrifugation, at a density of $1.220 \mathrm{~g} / \mathrm{ml}$. The isolated serum lipoproteins were then separated by gel filtration chromatography on $6 \%$ agarose. The overall recovery of the separated lipoprotein cholesterol was $90 \%$ or greater. In cord serum, four lipoprotein peaks were found, whereas three peaks were present in adult lipoproteins. The major lipoproteins of cord serum correspond to low density lipoprotein (LDL) and high density lipoprotein (HDL). Very low density lipoproteins (VLDL) were heterogeneous in cord serum. After gel filtration chromatography, the distribution of cord serum cholesterol is about $5 \%$ in peak $1,10 \%$ in peak $2,40 \%$ in peak 3 (LDL), and $45 \%$ in peak 4 (HDL). An additional difference between the lipoproteins isolated from cord serum and those from adult serum was the slower electrophoretic mobility of cord serum VLDL in agarose gel.

\section{Speculation}

The fetus, during the later stages of pregnancy, accumulates fat at an accelerating rate. Triglycerides, synthesized by the liver, are secreted as VLDL and transported to adipose tissue for degradation, probably by lipoprotein lipase.

The heterogeneity of cord blood VLDL and the presence of a significant amount of an intermediate lipoprotein fraction (designated peak 2) may be related to a partial metabolic block in the conversion of VLDL lipoproteins to smaller lipoproteins such as LDL.

Although there have been numerous reports dealing with the concentration of lipids and lipoproteins in cord blood, no comprehensive studies concerning the distribution, structure, and chemical composition of cord serum lipoproteins have been described $(1,3,6,7,8,11,13,17,18)$. Glueck et al. (7) have emphasized the importance of determination of cord blood cholesterol for the detection of heritable type II hyperlipoproteinemia. More recently, Kwiterovich et al. (11) have suggested that the concentration of low density lipoprotein cholesterol is of greater significance in the ascertainment of the affected child with type II hyperlipoproteinemia.

In order for cord blood screening techniques to be of diagnostic significance, a more complete understanding of the relation between cord serum lipids and lipoproteins will be required. To further study this relationship, a procedure has been used where 
quantitative recovery of cord serum lipoproteins was achieved by a single ultracentrifugation step. The gel chromatographic profile and the electrophoretic mobility of cord serum lipoproteins have been compared to those of normal adults. In addition, these studies have quantified the distribution of cholesterol among lipoproteins in cord serum.

\section{METHODS}

Normal full term infants, with 1- and 5-min Apgars of $\geq 9$ whose mothers had an uncomplicated gestation, labor, and delivery, were selected for study. Umbilical cord samples were obtained and allowed to stand at room temperature for 30-60 $\min$. The serum was separated from the clot by centrifugation at $4^{\circ}$. A portion of the serum was removed for the determination of cholesterol and immunoglobulin $M(\operatorname{IgM})$, and then disodium (ethylenedinitrilo) tetraacetate (EDTA) and thimerosal were added at a concentration of $1 \mathrm{mg} / \mathrm{ml}$ and $0.1 \mathrm{mg} / \mathrm{ml}$, respectively. The serum lipoproteins were isolated from individual cord serum (Table 1) or serum was pooled from four to seven individuals (Table 2, Figs. 1-4). The concentrations of total cord serum cholesterol and of IgM were determined on the individual serum. After pooling the serum, the total cholesterol was determined on an aliquot of the serum pool. The serum remained at $4^{\circ}$ and the isolation of the lipoproteins was started within $72 \mathrm{hr}$ after collection.

Total cord serum lipoproteins were isolated by a single ultracentrifugation at density $1.22 \mathrm{~g} / \mathrm{ml}$. To establish the ultracentrifugal flotation characteristics of cord serum lipoproteins, sequential preparative ultracentrifugation was conducted at density $1.006,1.063$, and $1.22 \mathrm{~g} / \mathrm{ml}$. Solid $\mathrm{KBr}$ was used to adjust the solution density (9). Ultracentrifugation was carried out at $17^{\circ}$ in a Beckman L2-65B ultracentrifuge with an SW 40 rotor (Beckman Instruments, Inc., Fullerton, Calif.).

The lipoproteins isolated at 1.006 and $1.063 \mathrm{~g} / \mathrm{ml}$ were ultracentrifuged for 2.0-2.4 $\times 10^{8} \mathrm{~g}$-min, whereas lipoproteins isolated at $1.220 \mathrm{~g} / \mathrm{ml}$ were ultracentrifuged $5 \times 10^{8} \mathrm{~g}$-min. After centrifugation, the top $1.5 \mathrm{ml}$ of lipoprotein-rich supernatant solution were removed by tube slicing.

Column chromatography was carried out by the method of Rudel et al. (14) in a column $(1.5 \times 90 \mathrm{~cm})$ packed with $6 \%$ agarose beads (Bio-Gel A-5m, 200-400 mesh, Bio-Rad Laboratories, Richmond, Calif.) and operated at $4^{\circ}$. The agarose gel was equilibrated with $0.15 \mathrm{M} \mathrm{NaCl}$, which contained $0.05 \%$ EDTA, pH 7.2, and the same solution was used for eluting the lipoproteins. The flow rate was approximately $10 \mathrm{ml} / \mathrm{hr}$, and 5 $\mathrm{ml}$ fractions were collected. Each fraction was monitored in a Zeiss PMQ spectrophotometer at $280 \mathrm{~nm}$. The void volume $\left(\mathrm{V}_{0}\right)$ of the column was $150 \mathrm{ml}$ and the elution volume $\left(V_{c}\right)$ was 450 $\mathrm{ml}$.

Cholesterol was used to measure the recovery of the lipoproteins. The concentrations of cholesterol in the serum, in the supernatant and infranatant lipoproteins after ultracentrifugation, and in the gel filtration column fractions were measured by the method of Rudel and Morris (15). HDL cholesterol was determined by the method of Burstein and Samaille (2). IgM was determined by immunoradial diffusion using a commercial preparation of low IgM standard (19). Agarose electrophoresis was carried out by a slight modification of the procedure of Noble (12).

\section{RESULTS}

The quantitative isolation and recovery of total cord serum lipoprotein cholesterol from individual cord sera are shown in Table 1 . The mean recovery of total cholesterol after ultracentrifugation was $100 \%$ (range $91-110 \%$ ). The cholesterol found in the supernatant lipoprotein solution accounted for $96 \%$ of the total serum cholesterol (range 94-98\%).

To establish the recovery of lipoprotein cholesterol, about 25 $\mathrm{ml}$ cord sera were pooled and, following the ultracentrifugal
Table 1. Recovery and distribution of cord serum cholesterol (Chl) after ultracentrifugation (UC)'

\begin{tabular}{|c|c|c|c|c|c|c|c|}
\hline & \multicolumn{6}{|c|}{ Patient } & \multirow{2}{*}{$\begin{array}{c}\text { Mean } \\
\text { Chl } \\
\text { re- } \\
\text { cov- } \\
- \text { ery, } \\
\%\end{array}$} \\
\hline & 1 & 2 & 3 & 4 & 5 & 6 & \\
\hline $\mathrm{Chl}, \mathrm{mg} / \mathrm{dl}$ & 35 & 55 & 72 & 59 & 67 & 51 & \\
\hline Chl-UC, mg & 3.15 & 4.95 & 5.04 & 5.31 & 6.03 & 4.59 & \\
\hline $\begin{array}{c}\% \text { Chl re- } \\
\text { covered }\end{array}$ & 109 & 91 & 107 & 94 & 99 & 102 & 100 \\
\hline $\begin{array}{l}\text { \% Chl in } \\
\text { superna- } \\
\text { tant lipo- } \\
\text { proteins }\end{array}$ & 94 & 96 & 98 & 95 & 97 & 97 & 96 \\
\hline
\end{tabular}

${ }^{1} \mathrm{Chl}, \mathrm{mg} / \mathrm{dl}$ : total serum cholesterol; Chl-UC, $\mathrm{mg}$ : the amount of serum cholesterol added to the ultracentrifuge tube (the volume of serum was 7-9 ml); \% Chl recovered: $\frac{\text { Supernatant } \mathrm{Chl}+\text { infranatant } \mathrm{Chl}}{\text { Serum } \mathrm{Chl} \text { added to UC tube }}: \times 100$; $\% \mathrm{Chl}$ in supernatant lipoproteins: $\frac{\text { Supernatant } \mathrm{Chl}}{\text { Total recovered } \mathrm{Chl}} \times 100$.

Table 2. Distribution of cholesterol (Chl) in lipoproteins separated by agarose column chromatography ${ }^{1}$

\begin{tabular}{|c|c|c|c|c|c|c|c|}
\hline \multirow{2}{*}{$\begin{array}{c}\text { Cord } \\
\text { serum } \\
\text { pool }\end{array}$} & \multirow{2}{*}{$\begin{array}{l}\text { Total } \\
\text { Chl, } \\
\mathrm{mg} / \\
\mathrm{dl}\end{array}$} & \multicolumn{4}{|c|}{$\%$ Cholesterol in } & \multicolumn{2}{|c|}{ Chl recovered } \\
\hline & & $\begin{array}{c}\text { Peak } \\
1^{2}\end{array}$ & $\begin{array}{c}\text { Peak } \\
2\end{array}$ & $\begin{array}{c}\text { Peak } \\
3\end{array}$ & $\begin{array}{c}\text { Peak } \\
4\end{array}$ & UC & $\begin{array}{l}\text { Col- } \\
\text { umn }\end{array}$ \\
\hline 1 & 44 & 5.8 & 11.5 & 37.8 & 44.9 & 96 & 90 \\
\hline 2 & 64 & 4.5 & 9.8 & 37.4 & 48.3 & 93 & 98 \\
\hline 3 & 58 & 1.0 & 10.4 & 45.3 & 43.3 & 92 & 94 \\
\hline 4 & 62 & 1.6 & 8.3 & 31.1 & 59.0 & 102 & $81^{3}$ \\
\hline
\end{tabular}

${ }^{1}$ Cord serum was pooled and about $25 \mathrm{ml}$ were ultracentrifuged at $1.220 \mathrm{~g} / \mathrm{ml}$ and the supernatant lipoproteins were applied to a $6 \%$ agarose column. UC: ultracentrifugation.

${ }^{2}$ Recovery of cholesterol $(\mathrm{Chl})$ in the supernatant lipoproteins following ultracentrifugation (see Footnote 1 to Table 1).

${ }^{3}$ An unknown amount of this sample was lost during application to the column.

isolation, the supernatant lipoproteins were separated by gel filtration chromatography. In these studies, cholesterol recovery was monitored both after ultracentrifugation and after gel chromatography to provide an accurate index of lipoprotein recovery. These results, shown in Table 2 , reveal that a mean of $94 \%$ of cord serum cholesterol was found in the supernatant lipoproteins after ultracentrifugation (range 92-96\%). When the lipoproteins were separated subsequently by gel chromatography, a mean of $94 \%$ of the lipoprotein cholesterol (three samples), which was applied to the agarose column, was recovered (range 92-96\%) (an unknown amount of the lipoprotein concentrate of sample 4 was lost). Thus, the overall recovery of cholesterol was $90 \%$ or greater in the combined ultracentrifugation and gel filtration chromatography procedure.

Since these methods were nearly quantitative for the recovery of cord serum cholesterol, the lipoprotein elution profile was next characterized by relating the $280 \mathrm{~nm}$ optical density to the gel filtration chromatography elution volume. A typical gel elution pattern of total cord serum lipoproteins is shown in Figure 1. For comparison, the gel profile of total serum lipoproteins of a 22-year-old normolipidemic male (total cholesterol $136 \mathrm{mg} / \mathrm{dl}$; triglycerides $66 \mathrm{mg} / \mathrm{dl}$ ) is also shown.

In the cord serum sample, four peaks were observed, whereas only three peaks were found in the adult. Peaks 1,3 , and 4 of the cord serum correspond, in position of their elution from the gel filtration column, to adult VLDL, LDL, and $\mathrm{HDL}$, respectively (14). 


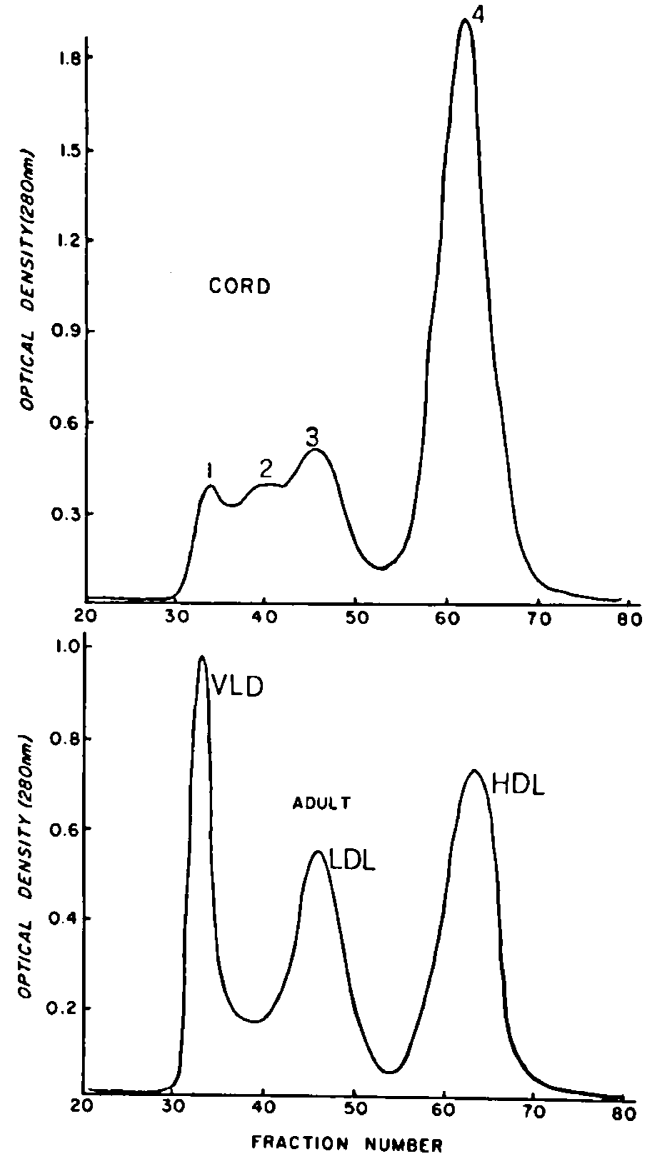

Fig. 1. Agarose gel column profile of cord and adult total serum lipoproteins plotted as a function of $280 \mathrm{~nm}$ optical density versus fraction number $(5 \mathrm{ml})$. The void volume of the column is fraction 3031. VLDL: very low density lipoproteins; LDL: low density lipoproteins; HDL: high density lipoproteins.
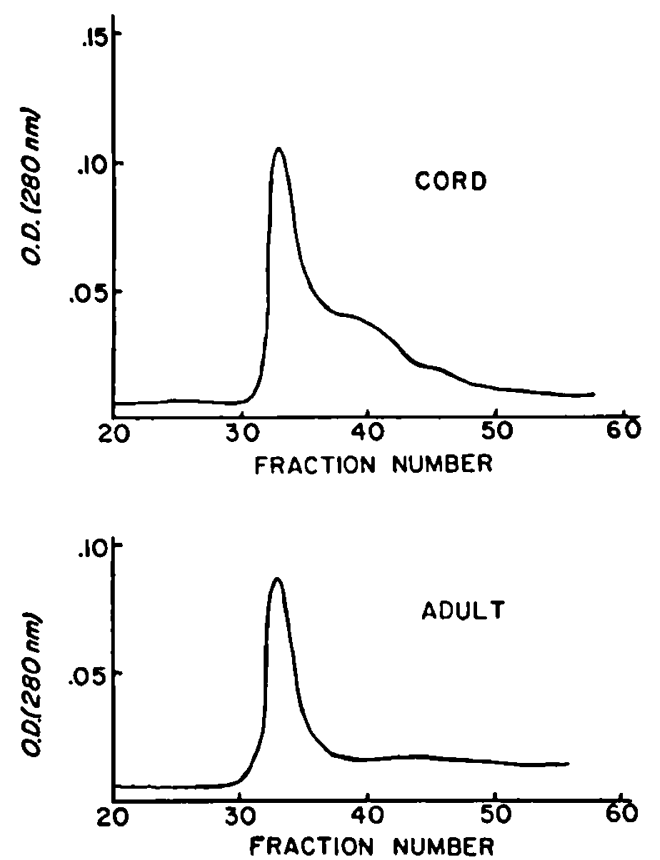

Fig. 2. Agarose gel column profile of cord and adult serum lipoproteins in density $<1.006$. See Figure 1 for details. Note the fractions 3650 are heterogeneous in cord serum density $<1.006 \mathrm{~g} / \mathrm{ml}$ lipoproteins. The adult profile rises to a single symmetrical peak. In the adult, very low density lipoproteins elute before fraction 40 .

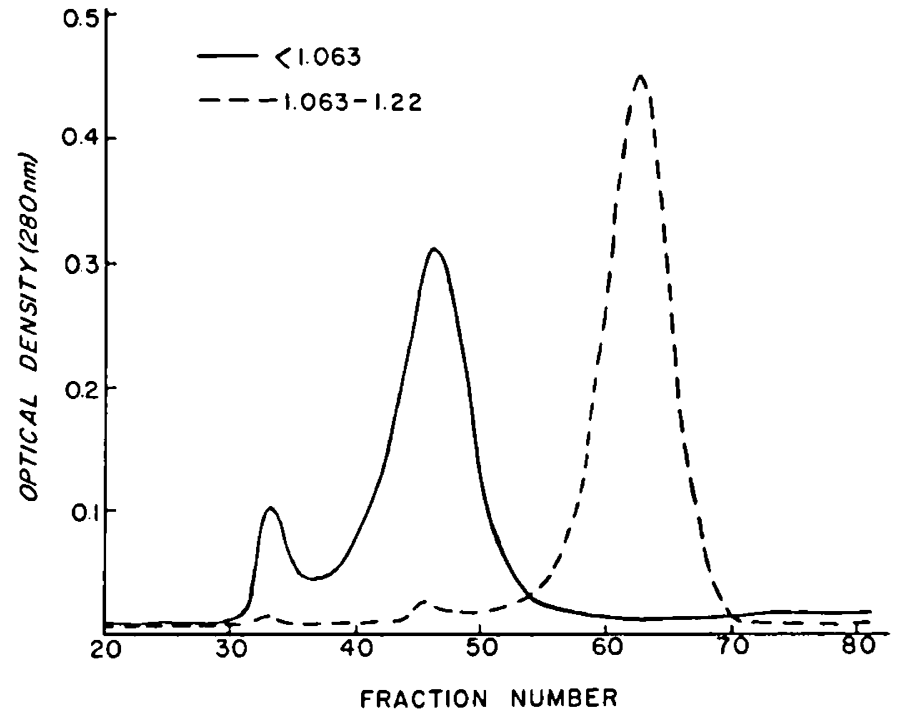

Fig. 3. Agarose gel column profile of cord serum, density $<1.063 \mathrm{~g} /$ $\mathrm{ml}$ lipoproteins (-, low density) and density $1.063-1.22 \mathrm{~g} / \mathrm{ml}$. Column operation is similar to Figure 1 . In this sample, in the density $<1.063$ lipoproteins, no peak 2 is obvious. However, an additional component is evident on the ascending limb of the major peak of the density $<1.063$ (low density) lipoproteins. There is no overlap between the lipoproteins of the density $<1.063 \mathrm{~g} / \mathrm{ml}$ and density $1.063-1.22 \mathrm{~g} /$ $\mathrm{ml}(---$, high density) fractions. A slight amount of unidentified peak 1 and peak 3 lipoproteins can be observed in the high density lipoproteins.

Because peaks 1 and 2 of cord serum were not well resolved, and, in addition, since our previous results (14) with adult lipoproteins had shown that VLDL was found in the column fractions near the column void volume, cord serum VLDL was isolated at a density of $1.006 \mathrm{~g} / \mathrm{ml}$. The $1.006 \mathrm{~g} / \mathrm{ml}$ supernatant lipoproteins were then subjected to gel filtration chromatography (Fig. 2). A major peak, which corresponds in position to peak 1 of the total cord serum lipoproteins, was observed in the VLDL. Also present were heterogenous, smaller sized lipoproteins, which contribute to peak 2 lipoproteins and, to a lesser extent, to the peak 3 lipoproteins. This figure also shows the chromatographic elution profile of the density $<1.006 \mathrm{~g} / \mathrm{ml}$ lipoproteins, isolated by the same procedure, from an adult (total serum cholesterol $146 \mathrm{mg} / \mathrm{dl}$; triglycerides $42 \mathrm{mg} / \mathrm{dl}$ ). In contrast to the heterogeneity of the cord serum lipoproteins of density $<1.006 \mathrm{~g} / \mathrm{ml}$, the corresponding fraction from the adult emerged from the agarose column as a single, sharp symmetrical peak.

In Figure 3, the gel elution profiles of cord serum lipoproteins isolated by sequential ultracentrifugation at $1.063 \mathrm{~g} / \mathrm{ml}(-)$ and $1.220 \mathrm{~g} / \mathrm{ml} \mathrm{(-})$ are shown. Peak 1 is clearly observed at the $V_{0}$ in the 1.063 supernatant lipoproteins. In this sample, although peak 2 is not well defined, an additional component can be seen as the initial part of the ascending arm of the peak 3 lipoproteins. The peak 3 lipoproteins were found in highest concentration in the same position (fraction 47) as that of the adult LDL in Figure 1. The elution pattern of the 1.063-1.22 g/ $\mathrm{ml}$ supernatant lipoproteins $(--)$ reveals a major symmetrical peak, which corresponds in position to that of the adult HDL (Fig. 1). Small peaks are also observed at the position of peak 1 and of peak 3 in the $1.063-1.22 \mathrm{~g} / \mathrm{ml}$ lipoproteins. Referring to Figure 3 , it is noteworthy that there is almost no overlap between the two major lipoproteins of cord serum employing the present gel filtration chromatography method.

The agarose gel electrophoresis patterns of cord and adult lipoproteins isolated by gel chromatography are depicted in Figure 4. The peak 1 lipoproteins of cord serum have a slower electrophoretic migration than the VLDL isolated from the adult 


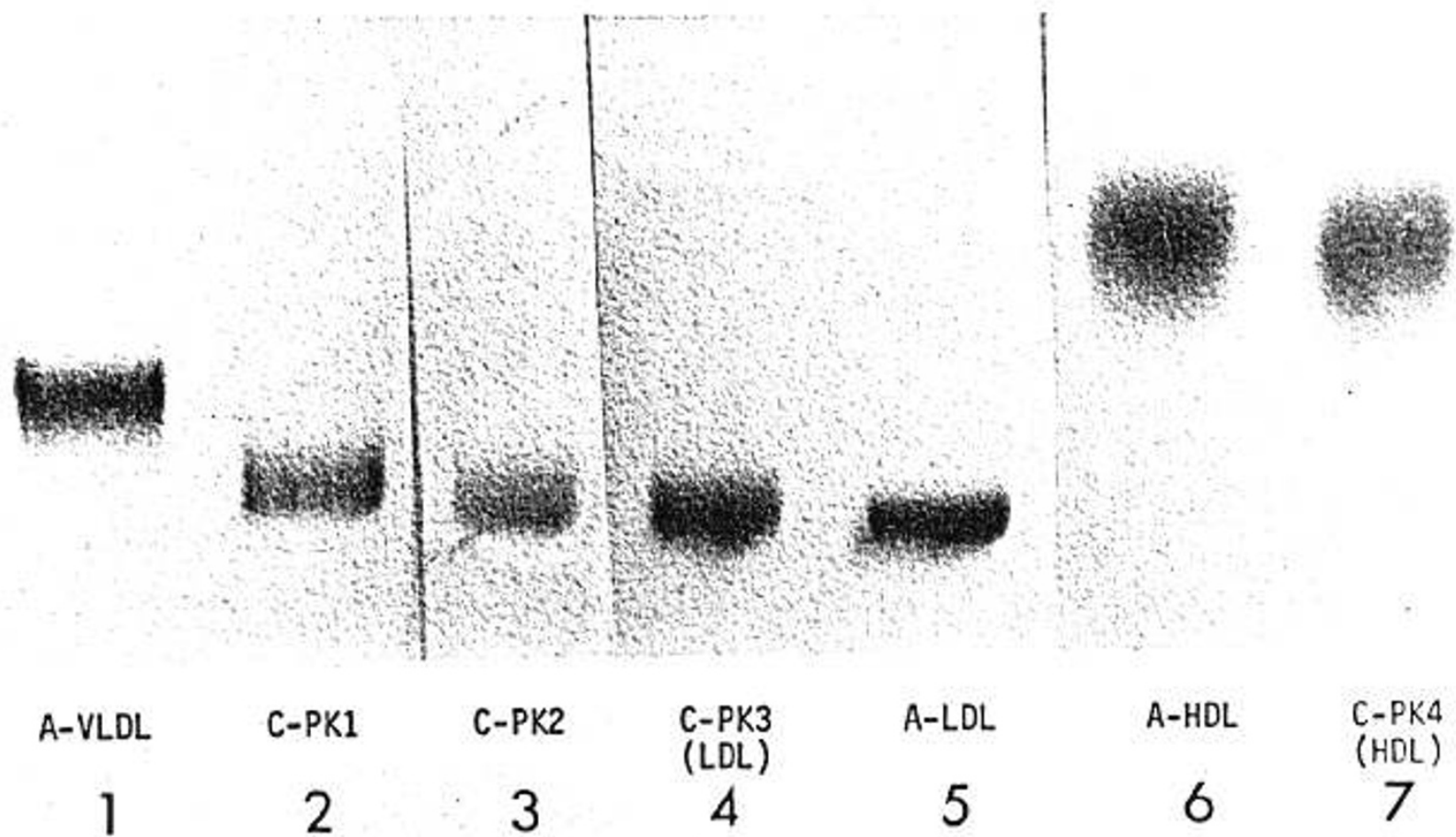

Fig. 4. Agarose gel electrophoresis pattern of adult and cord serum lipoproteins, isolated by gel filtration chromatography. Cord $(C)$ serum peak 1 $(P K I)$ lipoproteins have slower mobility than adult $(A)$ very low density lipoproteins (VLDL); cord peak 2 (C-PK2) is intermediate in mobility between VLDL and low density lipoprotein $(L D L)$; there is similar migration between LDL and high density lipoprotein ( $H D L)$ of cord and adult. 1: adult peak 1 (VLDL); 2: cord serum peak 1;3: cord serum peak 2; 4: cord serum peak 3 (LDL); 5: adult serum peak 2 (LDL); 6: adult serum peak 3 (HDL); 7: cord serum peak 4 (HDL).

(gel patterns 1 and 2, Fig. 4). In addition to the electrophoresis pattern shown, we have compared the electrophoretic mobility of peak 1 lipoproteins in 10 other cord sera to that of adult VLDL. In every sample, the lipoproteins of peak 1 of cord serum had a lesser mobility than those of adult VLDL. We have also separated cord serum lipoproteins by ultracentrifugation at density $1.006 \mathrm{~g} / \mathrm{ml}$ and have observed lipoproteins which correspond in electrophoretic mobility to those lipoproteins of peak 1 isolated by gel chromatography (figure not shown); in particular, we have not observed $\beta$-VLDL.

The lipoproteins found in pcaks 2 and 3 of cord serum (gel patterns 3 and 4 of Fig. 4 ) have an electrophoretic mobility slightly faster than LDL of the adult (gel pattern 5). Peak 2 lipoproteins of cord blood migrated slightly ahead of peak 3 lipoproteins (compare gel patterns 3 and 4). Peak 4 lipoproteins of cord serum, (gel pattern 7, Fig. 4) and adult HDL (gel pattern 6) have a similar electrophoretic mobility. Each lipoprotein fraction separated by gel filtration chromatography had a single lipoprotein staining band.

After separation of the cord serum lipoproteins by gel filtration chromatography, the distribution of cholesterol was about $5 \%$ in peak $1,10 \%$ in peak $2,40 \%$ in peak 3 , and $45 \%$ in peak 4 (Table 2). Since sample 4 was not recovered in high yield from the agarose column, we compared the HDL cholesterol concentration determined by the heparin-manganese procedure (2) to that found by column chromatography, in which $59 \%$ of total cholesterol was found in peak 4 (HDL). The HDL cholesterol measured by heparin-manganese was $35.8 \mathrm{mg} / \mathrm{dl}$, whereas the corresponding value from column cholesterol was $36.6 \mathrm{mg} / \mathrm{dl}$. The close agreement between these two values suggests that a selective loss of lipoproteins did not occur in sample 4 .

\section{DISCUSSION}

Because the effects of labor and delivery in circulating lipids and lipoproteins of the fetus have not been defined (17), we selected normal pregnancies and delivery of full term infants with Apgar $\geq 9$ for the present studies. Since this study was designed to characterize cord serum lipoproteins from normolipidemic term infants, an upper limit of cholesterol concentration of $85 \mathrm{mg} / \mathrm{dl}$ was chosen. In this laboratory, the mean cholesterol concentration of 500 cord serum was $62 \mathrm{mg} / \mathrm{dl} \pm 16 \mathrm{mg}$ dl (standard deviation). This value is quite similar to that reported from other laboratories $(7,18)$. Thus, the present studies of cord serum lipoproteins are representative of a normal population.

The present studies have shown that it is possible to recover, separate, and identify the lipoproteins of cord serum by procedures which we have previously found suitable for characterization of adult serum lipoproteins (14).

The gel filtration profile of separated cord serum lipoproteins showed some features which were characteristic of all samples. The first feature was the presence of a small peak (peak 1) which emerged from the agarose column slightly after the $V_{0}$ of the column; secondly, peak 3 and peak 4 cord serum lipoproteins were eluted from the column in precisely the same position as adult LDL and HDL, respectively. The third feature was that peak 3 and peak 4 lipoproteins accounted for $85 \%$ or more of the total cord lipoprotein cholesterol. Fourth, electrophoretic mobility of the major cord serum lipoproteins was similar although not identical to the corresponding adult lipoproteins, and finally, each lipoprotein peak contained only a single lipid staining band after agarose gel electrophoresis.

The most variable region of the cord serum lipoprotein gel profile was between the descending limb of peak 1 and the ascending limb of peak 3. Although most samples showed a definite peak in this region (Fig. 1), obvious heterogeneity on the ascending limb of peak 3 was occasionally found without a definite peak (Fig. 3). When compared to adult lipoproteins, cord serum lipoproteins were poorly resolved in this region. For example, Figure 1 shows that even though the maximum optical density of peak 1 cord lipoproteins was 0.45 compared to 0.96 
for adult VLDL, the trough between peak 1 and peak 2 of cord lipoproteins did not go below 0.38 , whereas in the adult, the trough was less than 0.20 in the identical region of the chromatographic profile. Irrespective of the gel profile pattern, about 10 $15 \%$ of the total lipoprotein cholesterol was found in these lipoproteins.

To better define these cord lipoproteins, ultracentrifugation at density $1.006 \mathrm{~g} / \mathrm{ml}$ and separation by gel filtration was conducted. Unexpectedly, a heterogeneous population of VLDL was found using $6 \%$ agarose (Fig. 2). Although the major peak corresponded to peak 1 of the total lipoproteins, several populations of smaller VLDL were also present. By contrast, heterogeniety of adult serum VLDL has not been observed, using $6 \%$ agarose columns as the separation medium, in any adult sample we have studied, even when the serum triglyceride concentration was as high as $400 \mathrm{mg} / \mathrm{dl}$.

These observations on the cholesterol and lipoprotein distribution in cord blood suggest metabolic alteration in the ability of the fetus to catabolize lipoproteins as compared to the adult. In the fetus, glucose has been considered the primary metabolic fuel as well as a major precursor of adipose tissue triglycerides $(10,16)$. In the last trimester of pregnancy, a period in which maximal fetal synthesis and deposition of adipose tissue triglycerides occur, the nutritional state of the fetus can be considered as high carbohydrate-low fat. The fetal liver may thus be a major organ for the synthesis of triglycerides. These newly hepaticsynthesized triglycerides are then incorporated into VLDL for transport to the adipose tissue where VLDL triglycerides are deposited. Recent evidence suggests that LDL apoproteins in the adult human are derived from the breakdown of VLDL (4, $5)$. Thus, a major interplay exists between the liver and the adipose tissue for the maintenance of normal balance among synthesis, degradation, concentration, and distribution of the major serum lipoproteins. The relatively high percentage of cholesterol found in VLDL and intermediate heterogeneous lipoproteins (peak 2) of cord blood, and not in adult serum, suggests a limitation in the ability of the fetus to degrade VLDL completely to LDL. For example, there may be a diminished lipoprotein lipase activity.

Little is known about the detailed structure of cord serum lipoproteins. The present study shows that it is possible to separate cord serum lipoproteins in sufficient quantity for greater in-depth examination. As more information on the metabolism of cord serum lipoproteins becomes available, insight on the diagnosis of familial hyperlipoproteinemia will undoubtedly be gained.

\section{CONCLUSION}

Total cord serum lipoproteins have been isolated from normal infants by combined preparative ultracentrifugation and gel filtration chromatography. About $85 \%$ of the total lipoproteincholesterol was found in column fractions, which were similar to LDL and HDL of adult lipoproteins isolated under similar con- ditions. VLDL of cord serum was heterogenous and the ge filtration profile of this fraction was in marked contrast to thy corresponding fraction from adults, which emerged from the column as a single symmetrical peak. In addition, an intermediate lipoprotein fraction, which contained $10-15 \%$ of cord serum cholesterol, was present in each sample and did not have a correspondent in adult lipoproteins.

Lipoprotein electrophoresis in agarose gel also demonstrated differences between cord lipoproteins and those of normal adult blood.

\section{REFERENCES AND NOTES}

1. Brody, S., and Carlson, L. A.: Plasma lipid concentrations in the newborn with special reference to the distribution of the different lipid fractions. Clin. Chim. Acta, 7: 694 (19t2).

2. Burstein, M., and Samaille, J.: On the rapid determination of cholesterol bound to alpha- and beta-lipoproteins of the serum. Clin. Chim. Acta, 5: 609 (1960).

3. Dyerberg, J., Hjorne, N., Nymand, G., and Olsen, J. S.: Reference values for cord blood lipid and lipoprotein concentrations. Acta Paediat. Scand., 63: 431 (1974).

4. Eisenberg, S., Bilheimer, D. W., Levy, R. I., and Lindgren, F. T.: On the metabolic conversion of human plasma very low density lipoprotein to low density lipoprotein. Biochim. Biophys. Acta, 326: 361 (1973).

5. Eisenberg, S., and Levy, R. I.: Lipoprotein metabolism. Advan. Lipid Res., 13: 1 (1975).

6. Fredrickson, D. S., and Breslow, J. L.: Primary hyperlipoproteinemia in infants. Ann. Rev. Med., 24: 315 (1973).

7. Glueck, C. J., Jueckman, F., Schoenfield, M., Steiner, P., and Pearse, W.: Neonatal familial type II hyperlipoproteinemia: Cord blood cholesterol in 1800 births. Metabolism, 20: 597 (1971).

8. Glueck, C. J., Steiner, P., and Leuba, V.: Cord-blood low-density lipoprotein cholesterol: Estimation versus measurement with the preparative ultracentrifuge. J. Lab. Clin. Med., 82: 467 (1973).

9. Hatch, F. T., and Lees, R. L.: Practical methods for plasma lipoprotein analysis. Advan. Lipid Res., 6: 1 (1968).

10. Hull, D.: Storage and supply of fatty acids before and after birth. Brit. Med. Bull., 31 : 32 (1975).

11. Kwiterovich, P. O., Levy, R. I., and Fredrickson, D. S.: Neonatal diagnosis of familial type II hyperlipoproteinemia. Lancet, $i$ : 118 (1973).

12. Noble, R. P.: Electrophoretic separation of plasma lipoproteins in agarose gel. J. Lipid Res., 9: 693 (1968).

13. Rafstedt, S.: Studies on serum lipids and lipoproteins in infancy and childhood. Acta Paediat. Scand. Suppl., 102: 1 (1955).

14. Rudel, L. L., Lee, J. A., Morris, M. D., and Felts, J. M.: Characterization of plasma lipoproteins separated and purified by agarose-column chromatography. Biochem. J., 139: 89 (1974).

15. Rudel, L. L., and Morris, M. D.: Determination of cholesterol using ophthalaldehyde. J. Lipid Res., 14: 364 (1973).

16. Shelley, H. J., Bassett, J. M., and Milner, R. D. G.: Control of carbohydrate metabolism in the fetus and newborn. Brit. Med. Bull., 31: 37 (1975).

17. Tsang, R., Glueck, C. J., Evans, G., and Steiner, P. M.: Cord blood hypertriglyceridemia. Amer. J. Dis. Child., 127: 78 (1974).

18. Wille, L. E., and Phillips, G. B.: Lipoprotein and lipid composition of neonatal serum. Clin. Chim. Acta, 34: 457 (1971).

19. Immuno-plate, Hyland Laboratories, Oakland, Calif.

20. We gratefully acknowledge the skilled technical assistance of Mrs. Rosa Haidar.

21. Requests for reprints should be addressed to: M. D. Morris, Ph.D., Department of Pediatrics, University of Arkansas for Medical Sciences, 4301 W. Markham St., Little Rock, Ark. 72201 (USA).

22. Received for publication June 14, 1976.

23. Accepted for publication October 27, 1976. 